\title{
Potential Use of Tropical Grass for Deferment in Semi-Arid Region
}

\author{
Ana Clara R. Cavalcante1, Jucivânia F. Araújo², Maria do Socorro Carneiro², \\ Henrique A. Souza1, Rafael G. Tonucci', Marcos Cláudio P. Rogerio', \\ Elayne Cristina G. Vasconcelos ${ }^{2}$ \\ ${ }^{1}$ Division of Forage and Soil Science, Embrapa Goats and Sheep, Sobral, Brazil \\ ${ }^{2}$ Animal Science Department, Federal University of Ceará, Fortaleza, Brazil \\ Email: ana.clara@embrapa.br, jucivaniafurtado@yahoo.com.br, msocorro@ufc.br, \\ henrique.souza@embrapa.br, rafael.tonucci@embrapa.br, marcos.claudio@cnpc.embrapa.br, \\ elaynegadelha@hotmail.com
}

Received 22 January 2014; revised 22 February 2014; accepted 3 March 2014

Copyright (C) 2014 by authors and Scientific Research Publishing Inc.

This work is licensed under the Creative Commons Attribution International License (CC BY). http://creativecommons.org/licenses/by/4.0/

(c) () Op Open Access

\begin{abstract}
Management evaluation of Panicum maximum cv. massai (Massai guineagrass) under deferment contributes as a strategic reserve of forage in the Brazilian semi-arid region. The objective of this study was to evaluate biomass production and nutritive value of massai guineagrass in an area of thinned caatinga vegetation in two deferment periods (60 and 90 days after plot-leveling cut) and four use periods (30, 60, 90 and 120 days after the end of the rain season), in a random blocks design arranged in a split-plot $(2 \times 4)$, with three replications. Extending the deferment period of massai guineagrass promoted elevation of the biomass components, but compromised the pasture quality due to increasing stem biomass. The massai guineagrass deferred 30 days after raining season started and should use $\mathbf{9 0}$ days after raining season ended to ensure a forage supply of appropriate nutritional value. The increase in relative air humidity and the occurrence of rainfall after water restriction stimulate regrowth, resulting in improved nutritional value of the grass.
\end{abstract}

\section{Keywords}

Enriched Caatinga; Crude Protein; Digestibility; Pasture Quality; Guineagrass Panicum maximum cv. Massai

\section{Implications}

The most important challenge to ruminant production in arid areas is to make sure that forage will be available during the dry period. Deferment is a management alternative that postponement of grazing or harvesting a specific 
management objective is regarded as an accumulation of forage for later use. Deferment has been an alternative to keep forage available for animal in pasture. There are only few grasses available with the characteristic needed for deferment use. Panicum maximum cv. massai (Massai guineagrass) has been presented as an interesting alternative to deferment due to its high leaf: stem ratio. This study identified the period of deferment and the use of massai guineagrass that offer forage in quantity and quality for grazing use.

\section{Introduction}

The production of forage plants in the semi-arid region is seasonal as a result of the short rainy period and the long dry season. In arid and semi-arid regions, during eight months of dry period on average, the roughage source available to ruminants consists basically of leaves fallen from the trees and bushes. However, it is found in insufficient amounts to maintain the production levels or even the maintenance of flocks.

Some management actions can be adopted to reduce the negative effects of forage of low quantity and poor quality in the dry season. Deferment is a management alternative that postponement of grazing or harvesting a specific management objective is regarded as an accumulation of forage for later use [1]. Pasture deferment, for example, emerges as a feasible alternative for using in semi-arid regions due to its low cost and ease adoption. This technique consists of reserving a given area during the rainy season, allowing the accumulated forage to be used during the dry period.

Santos and Cavalcante [2] stated that the most suitable forage plants for deferment were those which presented low stem accumulation and good retention of green leaves, resulting in lower reductions in nutritional value over time. There are few options of exotic forage plants to be used under deferment in the semi-arid region. Plant breeding has generated new options of plants with potential use in this environment. As is the case of massai guineagrass (Panicum maximum cv. massai), a Panicum cultivar released in 2001, which has shown adaptability to water stress, lower production seasonality, high green mass production and high leaf/stem ratio [3].

During the rainy season, in areas of natural pastures, animals choose to consume the native forage first. The enrichment of these areas with cultivated grasses makes them an option of strategic reserve to be consumed in the rainy season. However, for the best utilization of this forage resource, it is necessary to better determine the deferment and utilization periods of this grass, aiming at greater forage quality and quantity. Thus, the objective of this study was to determine the best times for deferment and use of the massai guinaegrass in a thinned-caatinga vegetation under the soil and climate conditions of the Brazilian semi-arid region.

\section{Material and Methods}

The experiment was conducted in an area of thinned and enriched caatinga with massai guineagrass (Panicum maximum cv. massai) at Embrapa Caprinos e Ovinos, in Sobral, Ceará, Brazil). The experimental area comprised $552 \mathrm{~m}^{2}$, at an altitude of $159 \mathrm{~m}$, located at $35^{\circ} 10^{\prime} 29^{\prime \prime}$ south latitude and $95^{\circ} 83^{\prime} 98^{\prime \prime}$ west longitude. The region has a hot semi-arid climate BShw' type, according to the Köppen classification, with average annual precipitation of $750 \mathrm{~mm}$ and the soil is classified as Luvisol [4].

The upper 0 - $0.2 \mathrm{~m}$ layer of the soil was sampled for analysis of fertility, and the results indicated adequate levels of $\mathrm{P}, \mathrm{K}, \mathrm{Ca}$ and $\mathrm{Mg}$, requiring only application of $100 \mathrm{~kg}^{-1}$ urea, as production fertilization.

Precipitation, maximum and minimum temperature and relative air humidity climate data recorded during the experimental period are presented in Table 1.

The experimental period was from February 2 to October 31, 2011. A plot-leveling cut was performed $15 \mathrm{~cm}$ above the soil level 30 days after the beginning of the rainy season. Two deferment times were evaluated: 60 and 90 days after the plot-leveling cut, which composed the plots, and four utilization periods (30, 60, 90 and 120 days after the end of the rainy period), which were the sub-plots. The experiment was set in a randomized-blocks design in a split-plot arrangement, with three replications.

For each deferment and utilization period, the following pasture structural characteristics were evaluated: masses of forage and its morphological components, dry masses of total forage (TFDM), dead forage (DFDM), green forage (GFDM), green leaf blades (LBDM) and green stems (GSDM), live/dead material ratio (LM/DM) and leaf/stem ratio (L/S).

For every cut, both in deferment and under utilization, two $1 \mathrm{~m}^{2}$ frames were cast over the area and the forage 
Table 1. Precipitation, temperature and relative air humidity in the area of the massai guineagrass deferred in 2011 Sobral/CE, Brazil.

\begin{tabular}{|c|c|c|c|c|c|c|c|c|c|}
\hline \multirow{2}{*}{ Climatic data } & \multicolumn{9}{|c|}{ Months } \\
\hline & Feb & Mar & Apr & May & Jun & Jul & Aug & Sep & Oct \\
\hline \multicolumn{10}{|c|}{ Precipitation (mm) } \\
\hline Total per month & 78.0 & 153.8 & 279.5 & 129.5 & 53.0 & 19.0 & 0.0 & 0.0 & 57.0 \\
\hline \multicolumn{10}{|l|}{ Temperature } \\
\hline Lower & 21.1 & 20.6 & 20.1 & 20.1 & 17.7 & 18.0 & 18.0 & 18.3 & 19.0 \\
\hline Average & 32.9 & 29.4 & 29.0 & 29.0 & 27.8 & 29.0 & 30.5 & 31.5 & 31.7 \\
\hline Higher & 44.8 & 38.1 & 37.8 & 37.9 & 37.8 & 40.0 & 43.0 & 44.6 & 44.3 \\
\hline \multicolumn{10}{|c|}{ Relative air humidity } \\
\hline Lower & 32 & 45 & 43 & 54 & 39 & 27 & 18 & 17 & 15 \\
\hline Average & 64 & 70 & 68 & 75 & 67 & 61 & 55 & 56 & 55 \\
\hline Higher & 95 & 95 & 93 & 95 & 95 & 95 & 92 & 95 & 95 \\
\hline
\end{tabular}

within it was collected. A sub-sample of each frame containing approximately $300 \mathrm{~g}$ of fresh mass was separated into live and dead material; the former was fractioned into leaf blades and stems. All of these fractions were placed in a forced-ventilation oven at $55^{\circ} \mathrm{C}$ until reaching constant weights. Knowing the proportions of the morphological fractions in the green sub-sample and its respective percentages of dry matter, the biomass was estimated. For the times of use, the production of lodged forage was quantified and the cut was performed distinguishing the two fractions (lodged and non-lodged forage).

The pasture height $(\mathrm{PH})$ was measured before each cut of the different deferment periods, utilizing a sward-stick. Tiller density (TD) was counted manually with a $0.25 \mathrm{~m}^{2}$ frame. The number of live leaves per tiller was obtained by counting the number of live leaves in twenty tillers randomly chosen per treatment.

Intercepted photosynthetically active radiation (IPAR) and leaf area index (LAI) data were also measured with Accupar LP-80 ${ }^{\circledR}$.

The chemical composition was determined in the samples of massai guineagrass, for the deferment and utilization periods. These leaves were ground through a $1 \mathrm{~mm}$ sieve and prepared aiming at quantification of the dry matter (DM) contents at $105^{\circ} \mathrm{C}$; mineral matter, for the calculation of organic matter; and crude protein, according to the methodology described by Cunnif [5], and in vitro DM digestibility (IVDMD) according to Tilley \& Terry [6] [7]. To quantify the neutral detergent fiber (NDF), acid detergent fiber (ADF), cellulose, hemicellulose and lignin, the methodology proposed by Van Soest et al. [8] was used.

Results obtained were subjected to variance analyses by F test, and when significant for the plots, deployment was performed by applying Tukey's test of means $(\mathrm{p}<0.05)$ and regression analysis for the sub-plots and for the interaction. The statistical analyses were conducted on SAS software [9].

\section{Results and Discussion}

The deferment period had a significant effect on TFDM, GFDM, LBDM, GSDM, DFDM and L/S; the highest values were obtained in deferment at 90 days, with production of over $3300 \mathrm{~kg}$ TFDM (Table 2). This value is similar to that obtained by Moreira et al. [6] with buffel grass, which is the most recommended grass for cultivation in the semi-arid region.

It is important to highlight that almost $2000 \mathrm{~kg}$ of the TFDM produced at 90 days consisted of green material, and less than $10 \%$ were stem. Working with buffel grass in a similar trial, Sanchez et al. [10] obtained production of $151 \mathrm{~kg}$ DM per hectare of leaf, and $147 \mathrm{~kg}$ DM of stem. The leaf:stem ratio of the massai guineagrass was 7.3, whereas that of buffel grass was 1.0 in similar management.

The deferment period $\times$ utilization period interaction had a significant effect $(\mathrm{p}<0.05)$ on variables TFDM, GFDM, LBDM, GSDM, DFDM and L/S (Figure 1). Maximum total forage production (3901 kg/ha) was estimated in the deferment period of 90 days with utilization at 71 days.

For GFDM and LBDM, at 60 days, the model that best fit was the decreasing linear. The greatest estimated productions were $1797.5 \mathrm{~kg} / \mathrm{ha}$ GFDM and $1681 \mathrm{~kg} / \mathrm{ha}$ LBDM at 30 days of use. At 90 days it had showed a quadratic trend with a production peaks of $2486 \mathrm{~kg} / \mathrm{ha}$ GFDM at 49 days of use and $2308 \mathrm{~kg} / \mathrm{ha}$ LBDM at 33 
Table 2. Summary of the variance analysis for the structural characteristics of Panicum maximum cv. massai according to the deferment and utilization periods.

\begin{tabular}{|c|c|c|c|c|c|c|c|c|c|c|c|}
\hline Treatments & TFDM & GFDM & LBDM & GSDM & DFDM & $\mathrm{L} / \mathrm{S}$ & $\mathrm{PH}$ & $\mathrm{L} / \mathrm{T}$ & $\mathrm{TD}$ & IPAR & LAI \\
\hline Deferment (D) & & & $\mathrm{kg} \cdot \mathrm{ha}{ }^{-1}$ & & & & $\mathrm{~cm}$ & & Till. $/ \mathrm{m}^{2}$ & $\%$ & \\
\hline 60 & $1927 b$ & $1336 b$ & 1195b & $50.9 b$ & $839.3 b$ & $23.5 \mathrm{a}$ & 33.4 & 2.3 & 207 & 88.3 & 3.8 \\
\hline 90 & 3379a & 1988a & $1796 a$ & $246.8 \mathrm{a}$ & 1438a & $7.3 \mathrm{~b}$ & 34.9 & 2.3 & 200 & 89.4 & 4.6 \\
\hline $\mathrm{F}$ & $97.8^{*}$ & $41.3^{*}$ & $33.1^{*}$ & $85.0^{*}$ & $21.0^{*}$ & $14.6^{*}$ & $0.17^{\mathrm{ns}}$ & $4.0^{\mathrm{ns}}$ & $1.8^{\mathrm{ns}}$ & $0.5^{\mathrm{ns}}$ & $5.0^{\mathrm{ns}}$ \\
\hline $\mathrm{CV}_{1}(\%)$ & 13.6 & 14.9 & 16.5 & 34.9 & 28.1 & 61.4 & 26.8 & 4.4 & 6.4 & 4.4 & 20.8 \\
\hline \multicolumn{12}{|l|}{ Utilization (U) } \\
\hline 30 & 2441 & 1983 & 1980 & 56.8 & 306.9 & 34.9 & 47.3 & 3.0 & 302 & 91.9 & 4.8 \\
\hline 60 & 2862 & 1931 & 1648 & 202.4 & 1175 & 8.1 & 36.4 & 2.6 & 266 & 91.1 & 4.5 \\
\hline 90 & 2941 & 1704 & 1316 & 140.1 & 1574 & 9.4 & 25.9 & 2.0 & 139 & 88.7 & 3.9 \\
\hline 120 & 2367 & 1030 & 983.4 & 196.1 & 1499 & 5.0 & 27.3 & 1.6 & 107 & 83.7 & 3.8 \\
\hline F & $6.6^{*}$ & $23.5^{*}$ & $33.1^{*}$ & $4.2^{*}$ & $72.6^{*}$ & $12.9^{*}$ & $28.21^{*}$ & $46.5^{*}$ & $173^{*}$ & $14.9^{*}$ & $40.1^{*}$ \\
\hline $\mathrm{CV}_{2}(\%)$ & 10.4 & 13.3 & 13.1 & 54.3 & 14.7 & 49.0 & 13.4 & 10.3 & 8.7 & 2.6 & 4.4 \\
\hline $\mathrm{D} \times \mathrm{U}$ & $5.3^{*}$ & $4.7^{*}$ & $6.6^{*}$ & $4.8^{*}$ & $6.5^{*}$ & $7.6^{*}$ & $1.28^{\mathrm{ns}}$ & $1.7^{\mathrm{ns}}$ & $2.5^{\mathrm{ns}}$ & $1.6^{\mathrm{ns}}$ & $1.8^{\mathrm{ns}}$ \\
\hline
\end{tabular}

${ }^{\ddagger}$ TFDM (total forage dry mass), GFDM (green forage dry mass), LBDM (green leaf blades dry mass) GSDM (green stem dry mass), DFDM (dead forage dry mass), L/S (leaf/stem ratio), PH (pasture height), L/T (number of live leaves per tiller), TL (tiller density), IPAR (intercepted photosynthetically active radiation), LAI (leaf area index).
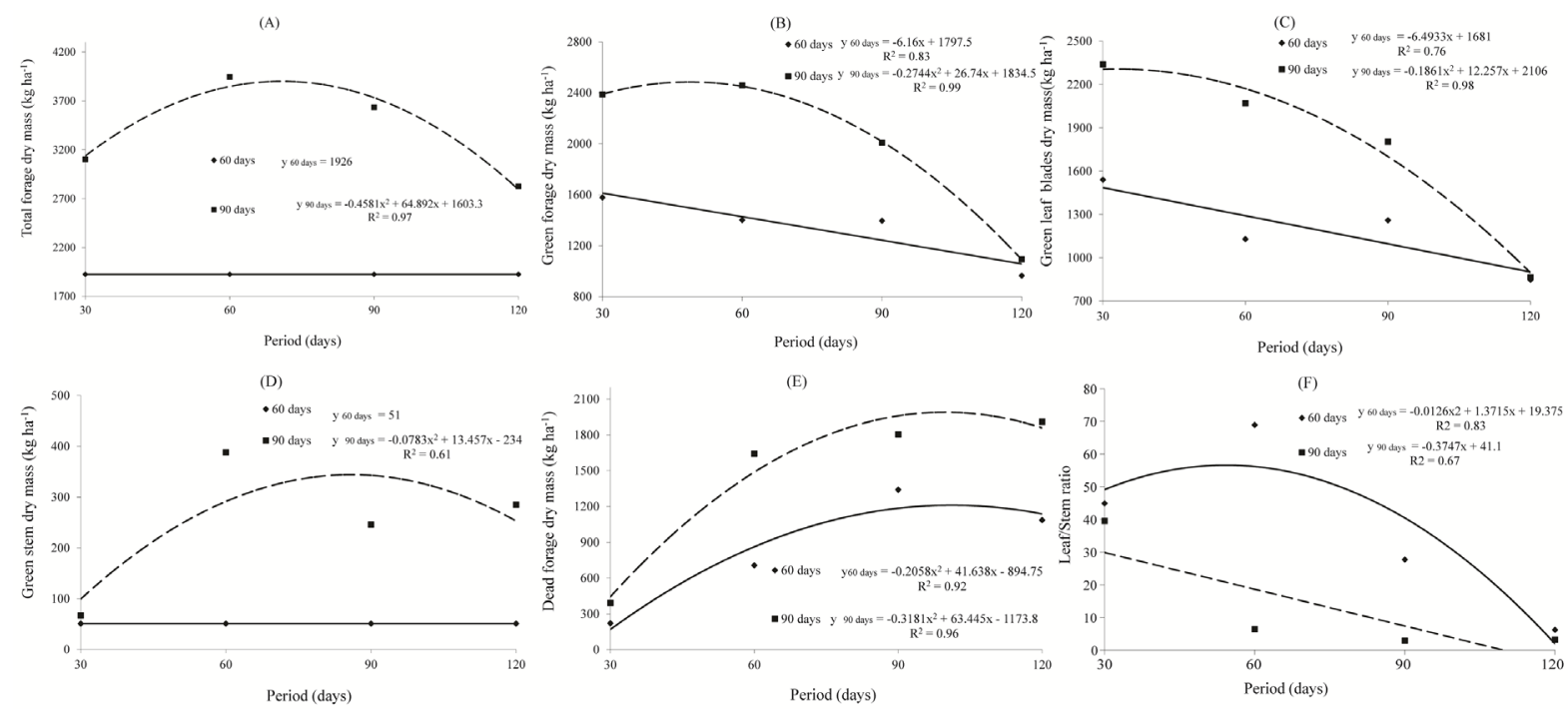

Figure 1. Total forage dry mass (A), green forage dry mass (B), green leaf blades dry mass (C), green stem dry mass (D), dead forage dry mass (E) and leaf/stem ratio (F) according to the periods of utilization and deferment of the deferred Panicum maximum cv. massai. The $\mathrm{R}^{2}$ values shown came from 24 observations (all replications values), based on SAS output. The dots are means of the observations and they were used only to illustrate trends and better show the curves' tendency.

days of use. The reduction in LBDM after 33 days is probably due to leaves senescence and increase in dead material (Table 2). Leaf blade dry mass is of great importance, since it is the most chosen portion by grazing animals [11]; thus pasture management must seek the greater leaf production.

Green stem dry mass (GSDM) did not show differences when there was deferment at 60 days (Figure 1(D)). At 90 days of deferment, a quadratic behavior was observed for this variable; maximum production of stems ( $344.19 \mathrm{~kg} / \mathrm{ha}$ ) was estimated at 86 days of use. Although the production of stems after this period reduced, it is important to remember that leaf production decreases linearly (Figure 1(C)), so pasture utilization is not recommended after 86 days.

Dead forage dry mass (DFDM) showed the same quadratic behavior $(\mathrm{p}<0.05)$ for the deferment periods of 60 and 90 days (Figure 1(E)); the highest accumulations of dead material were 1211.32 and $1989.7 \mathrm{~kg} / \mathrm{ha}$ for 60 
and 90 days of deferment, respectively, at 100 days of use. It is likely that after values close to the critical LAI were reached, the loss by leaf senescence intensified, which is a common fact at the final growth phase of grasses kept in regrowth for a long period [12].

The leaf/stem ratio (L/S) showed a quadratic behavior for the deferment time of 60 days, with maximum ratio estimated at 54 days of use, whereas at 90 days of deferment, this variable showed decreasing linear trend ( $\mathrm{p}<$ 0.05 ), in which, for every day of growth of the massai guineagrass, there was a decrease of 0.37 in the $\mathrm{L} / \mathrm{S}$ ratio (Figure 1(F)). This structural characteristic of massai guineagrass followed the same trend of the leaf component (Figures 1(C) and (D)), which is more important than the stem. The relative diminution of the availability of leaves affects the animal intake and consequently its performance [13] [14].

Studying the chemical composition of forage plants is essential to provide subsidies to define an appropriate concentrate and/or roughage supplementation [15], specially deferred forages given that tend to present lower nutritional value.

The time of utilization had a significant effect on the dry matter content, showing a quadratic behavior with maximum accumulation of dry matter at 97 days of utilization (Table 3).

There was significant interaction $(\mathrm{p}<0.05)$ between deferment and utilization periods of the deferred massai guineagrass leaves for crude protein (LCP) and leaf in vitro dry matter digestibility (LIVDDM) (Figure 2).

Out of expected, crude protein contents presented a quadratic behavior with minimum values at 88 and 122 days of use of the deferment periods of 60 and 90 days, respectively (Figure 2(A)). Despite this reduction, none of the values was lower than $7 \%$, which is the minimum quantity of CP for good ruminal functioning (VAN SOEST, 1994). This odd adjustment was not expected, since these values actually tend to reduce linearly. It must happened probably due to an atypically rainy period recorded in October (Table 1) allowing the grass to rapidly regrow. Characteristics like that are desirable for using it in semi-arid environment with low rain precipitations.

Table 3. Summary of the variance analysis of the chemical composition and in vitro dry matter digestibility (\%) of the morphological component leaf of Panicum maximum cv. massai under different periods of utilization and deferment.

\begin{tabular}{|c|c|c|c|c|c|c|c|c|c|}
\hline \multirow[b]{2}{*}{ Treatment } & \multicolumn{9}{|c|}{ Chemical composition of the leaf } \\
\hline & DM & $\mathrm{OM}$ & $\mathrm{CP}$ & NDF & $\mathrm{ADF}$ & HCEL & CEL & LIG & IVDMD \\
\hline Deferment (D) & \multicolumn{9}{|c|}{$\%$ in $\mathrm{DM}$} \\
\hline 60 & 49.9 & 91.8 & $8.5^{\mathrm{a}}$ & 74.3 & 42.2 & 32.4 & 36.1 & 5.4 & $41.6^{\mathrm{a}}$ \\
\hline 90 & 49.0 & 91.7 & $7.5^{\mathrm{b}}$ & 74.4 & 41.9 & 32.0 & 36.7 & 4.7 & $37.4^{\mathrm{b}}$ \\
\hline F test & $0.1^{\text {ns }}$ & $1.6^{\mathrm{ns}}$ & $5.4^{*}$ & $0.0^{\mathrm{ns}}$ & $0.1^{\mathrm{ns}}$ & $8.9^{\text {ns }}$ & $0.7^{\mathrm{ns}}$ & $4.5^{\mathrm{ns}}$ & $38.2^{*}$ \\
\hline $\mathrm{CV}_{1}(\%)$ & 16.1 & 0.2 & 4.4 & 1.9 & 6.5 & 0.9 & 4.7 & 14.9 & 4.1 \\
\hline \multicolumn{10}{|l|}{ Utilization (U) } \\
\hline 30 & 30.5 & 91.5 & 9.0 & 75.2 & 43.1 & 32.1 & 36.3 & 5.7 & 53.6 \\
\hline 60 & 42.0 & 91.8 & 7.5 & 75.2 & 41.1 & 34.4 & 35.8 & 4.9 & 42.3 \\
\hline 90 & 70.7 & 91.8 & 7.2 & 73.4 & 42.1 & 31.1 & 36.7 & 4.7 & 31.5 \\
\hline 120 & 54.8 & 91.9 & 8.3 & 73.5 & 42.0 & 31.1 & 36.9 & 5.0 & 30.7 \\
\hline F test & $30.1^{*}$ & $0.5^{\mathrm{ns}}$ & $2.6^{\mathrm{ns}}$ & $1.7^{\mathrm{ns}}$ & $1.6^{\mathrm{ns}}$ & $3.2^{\mathrm{ns}}$ & $0.5^{\mathrm{ns}}$ & $3.9^{\mathrm{ns}}$ & $96.3^{*}$ \\
\hline $\mathrm{CV}_{2}(\%)$ & 15.7 & 0.7 & 7.5 & 2.7 & 3.7 & 2.1 & 4.4 & 10.4 & 6.8 \\
\hline \multirow[t]{2}{*}{$\mathrm{D} \times \mathrm{U}$} & $0.5^{\mathrm{ns}}$ & $0.7^{\mathrm{ns}}$ & $6.0^{*}$ & $0.3^{\text {ns }}$ & $0.1^{\text {ns }}$ & $2.6^{\mathrm{ns}}$ & $0.4^{\mathrm{ns}}$ & $5.0^{\text {ns }}$ & $28.6^{*}$ \\
\hline & \multicolumn{9}{|c|}{ Chemical composition of the lodged leaf } \\
\hline \multicolumn{10}{|l|}{ Utilization (U) } \\
\hline 30 & 33.4 & 91.4 & 10.3 & 70.3 & 41.7 & 32.2 & 35.5 & 5.2 & 50.4 \\
\hline 60 & 46.4 & 91.3 & 7.4 & 70.6 & 38.6 & 32.4 & 33.5 & 4.2 & 35.7 \\
\hline 90 & 62.0 & 90.7 & 6.9 & 70.9 & 40.1 & 31.1 & 34.0 & 4.7 & 32.4 \\
\hline 120 & 59.0 & 91.2 & 7.4 & 71.2 & 39.3 & 31.8 & 33.2 & 5.0 & 29.7 \\
\hline $\mathrm{F}$ & $30.1^{*}$ & $1.5^{\mathrm{ns}}$ & $2.6^{\mathrm{ns}}$ & $14.2^{*}$ & $10.1^{*}$ & $2.6^{\mathrm{ns}}$ & $10.3^{*}$ & $2.0^{\mathrm{ns}}$ & $8.7^{*}$ \\
\hline $\mathrm{CV}_{2}(\%)$ & 11.6 & 0.7 & 9.1 & 1.4 & 2.5 & 2.9 & 2.2 & 16.6 & 20.7 \\
\hline
\end{tabular}

${ }^{\text {ns }}$ and ${ }^{*}$ : Not significant and significant at 5\%, respectively. DM (dry matter), OM (organic matter), CP (crude protein), NDF (neutral detergent fiber), ADF (acid detergent fiber), HCEL (hemicellulose), CEL (cellulose), LIG (lignin), IVDMD (in vitro dry matter digestibility). ${ }^{1}$ Coefficient of variation of the plot. ${ }^{2}$ Coefficient of variation of the sub-plot. 
(A)

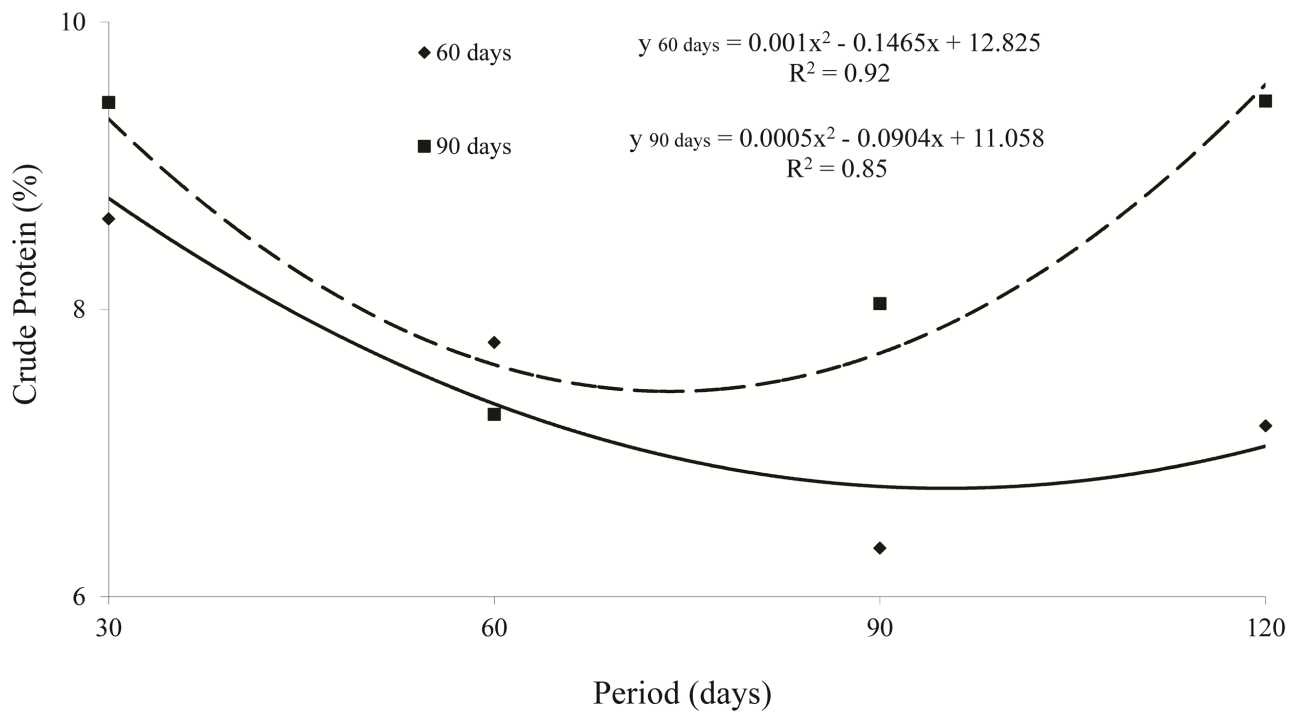

(B)

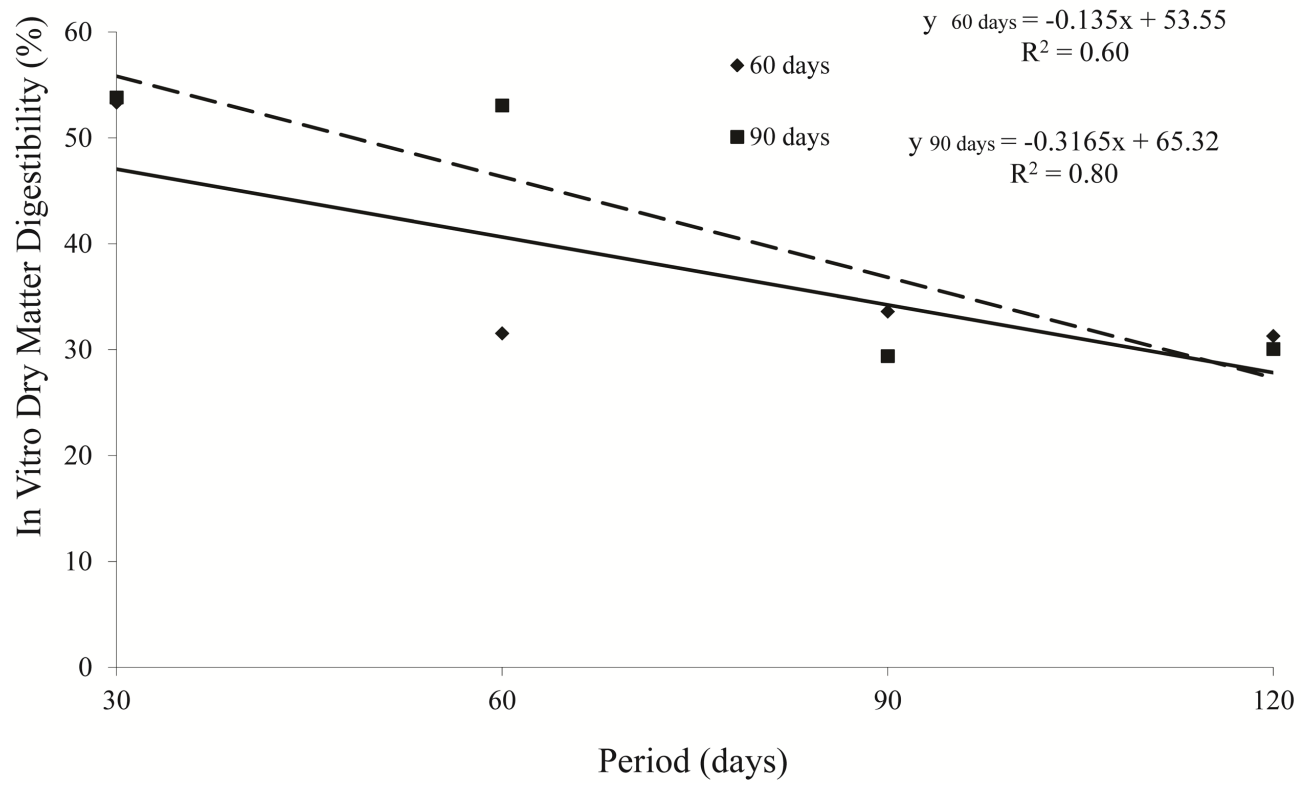

Figure 2. Crude protein (A) and in vitro dry matter digestibility (B) of the deferred massai guineagrass leaf according to the periods of deferment and utilization. The $\mathrm{R}^{2}$ values shown came from 24 observations (all replications values), based on SAS output. The dots are means of the observations and they were used only to illustrate trends and better show the curves' tendency.

The in vitro dry matter digestibility decreased linearly $(\mathrm{p}<0.05)$ as the period of utilization advanced (Figure 2(B)). The increase that occurred in the CP contents during the utilization period was not sufficient to change the IVDMD. Studies have indicated a relationship between increase in cell wall components and reduction of digestibility in deferred grasses [14] [16]. However, in our study, there was no significant increment in the fiber contents in the leaf component (Table 3). It is likely that the reduction in digestibility is more closely related to the types of cell-wall-forming tissues than to the quantity of fiber it contains [17].

Derrefed grass should not have a digestibility lower than $50 \%$, which characterizes low-quality roughage and compromises animal performance [18]. Under such conditions, the use of deferred massai guineagrass in the period of 60 and 90 days must occur before 31 and 48 days, respectively. 

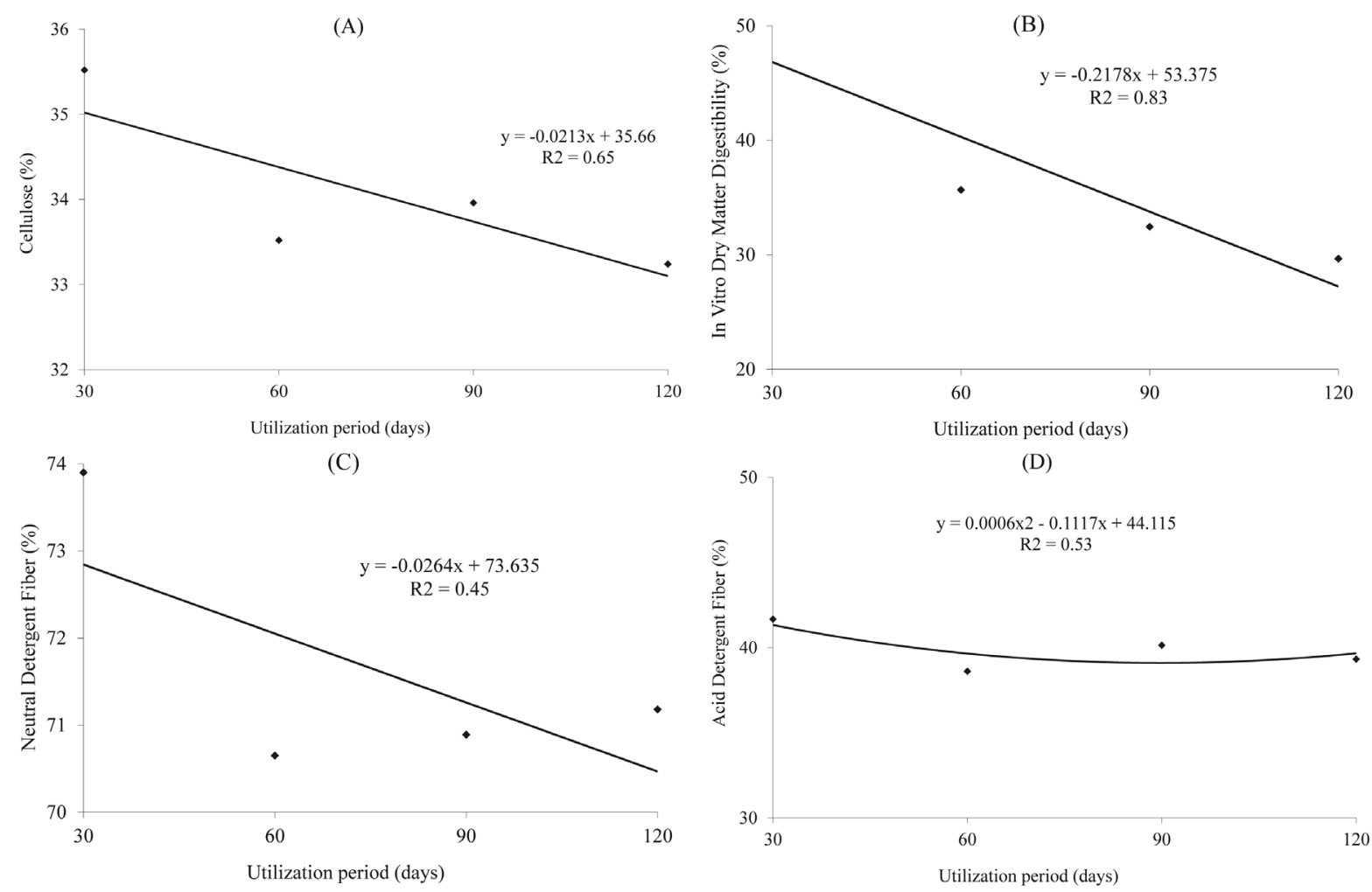

Figure 3. Cellulose (A), in vitro dry matter digestibility (B) neutral detergent fiber (C) and acid detergent fiber (D) of the morphological component leaf of the lodged forage of deferred Panicum maximum cv. massai pasture according to the periods of utilization. The $\mathrm{R}^{2}$ values shown came from 24 observations (all replications values), based on SAS output. The dots are means of the observations and they were used only to illustrate trends and better show the curves' tendency.

The drop in digestibility at the end of the utilization period to values around $27 \%$ in both deferred pasture periods compromises massai guineagrass quality. Unfortunately, for the most utilized grasses in the semi-arid, as is the case of buffel grass, these values have not exceeded 50\% [2] even on deferred pastures in shorter intervals.

Lodging was a remarkable characteristic of the massai guineagrass. This fraction composed mainly of leaves, still being consumed by grazing animal. Utilization period decreased NDF, ADF, CEL and IVDMD $(p<0.05)$ (Figure 3). For CEL and IVDMD, the decrease was linear, and for ADF, the reduction was quadratic, with its minimum at 93 days of utilization.

The inverse relationship between components NDF and IVDDM of the lodged forage illustrates what happens most of the times when the forage is not harvested at its best nutritional value: the fibrous components tend to increase, thereby reducing the forage digestibility.

\section{Conclusion}

It is suggested that we should utilize massai guineagrass as the choice of forage deferred use in semi-arid region due to its biomass accumulation properties and chemical composition. It is recommended to defer the forage 60 days after the beginning of the rainy period and use it 30 days after the end of the rainy period. Later deferment, at 90 days, also enables later use of the storage forage, around 50 days after the end of the rainy period.

\section{References}

[1] Allen, V.G., Batello, C., Berretta, E.J., Hodgson, J., Kothmann, M., Li, X., et al. (2011) An International Terminology for Grazing Lands and Grazing Animals. Grass and Forage Science, 66, 2-28. http://dx.doi.org/10.1111/j.1365-2494.2010.00780.x

[2] Santos, P.M. and Cavalcante, A.C.R. (2010) Diferimento do Uso de Pastagens. In: Pires, A.V., Ed., Bovinocultura de Corte, Fealq, Piracicaba, 497-508. 
[3] Jank, L., Valle, C. and Resende. R. (2011) Breeding Tropical Forages. Crop Breeding and Applied Biotechnology, 11, 27-34. http://dx.doi.org/10.1590/S1984-70332011000500005

[4] Santos, H.G., Jaconime, P.K.T., Oliveira, V.A., Oliveira, J.B., Coelho, M.R., et al. (2006) Sistema Brasileiro de Classificação de Solo. 2nd Edition, Embrapa Solos, Rio de Janeiro.

[5] Cunnif, P. (1995) Official Method of Analysis of AOAC International. AOAC International, Arlington.

[6] Moreira, J.N., Lira, M.A., Santos, M.V.F., Ferreira, M.A., Araújo, G.G.L., Ferreira, R.L.C., et al. (2006) Caracterização da Vegetação de Caatinga e da Dieta de Novilhos no Sertão de Pernambuco. Pesquisa Agropecuária Brasileira, 41, 1643-1651. http://dx.doi.org/10.1590/S0100-204X2006001100011

[7] Tilley, J.M.A. and Terry. R.A. (1963) A Two-Stage Techinique for in Vitro Digestion of Forage Crops. Grass and Forage Science, 18, 104-111. http://dx.doi.org/10.1111/j.1365-2494.1963.tb00335.x

[8] Van Soest, P.J., Robertson, J.B. and Lewis, B.A. (1991) Methods for Dietary Fiber, Neutral Detergent Fiber, and Nonstarch Polysaccharides in Relation to Animal Nutrition. Journal of Dairy Science, 74, 3583-3597. http://dx.doi.org/10.3168/jds.S0022-0302(91)78551-2

[9] SAS Institute (2004) SAS User’s Guide: Statistic. 7.50 Edition, SAS Institute, Cary.

[10] Sánchez, A., Mármol, J.F. and Araque, C. (2008) Producción de Materia Seca en Una Asociación Cenchrus ciliaris Leucaenaleucocephala al Aplazar su Utilización Durante la Época Seca. Zootecnia Tropical, 26, 117-123.

[11] Euclides, V.P.B., Thiago, L.R.L., Macedo, M.C.M. and Oliveira, M.P. (1999) Consumo Voluntário de Forragem de três Cultivares de Panicum Maximum sob Pastejo. Revista Brasileira de Zootecnia, 28, 1177-1185. http://dx.doi.org/10.1590/S1516-35981999000600002

[12] Parsons, A.J., Leafe, E.L. and Collet, B. (1983) The Physiology Grass Production under Grazing. II Photosynthesis, Crop Growth and Animal Intake of Continuously Grazed Swards. Journal of Applied Ecology, 20, 127-139. http://dx.doi.org/10.2307/2403381

[13] Keady, T.W.J. and Hanrahan, J.P. (2009) The Effects of Allowance and Frequency of Allocation of Deferred Herbage, and Grass Silage Feed Value, When Offered to Ewes in Mid-Gestation on Ewe and Lamb Performance and Subsequent Herbage Yield. Animal, 3, 879-890. http://dx.doi.org/10.1017/S1751731109004169

[14] Santos, M.E.R., Fonseca, D.M., Balbino, E.M., Monnerat, J.P.I.S. and Silva, S.P. (2009) Caracterização dos Perfilhos em Pastos de Capim-Braquiária Diferidos e Adubados com Nitrogênio. Revista Brasileira de Zootecnia, 38, $643-649$. http://dx.doi.org/10.1590/S1516-35982009000400008

[15] Santana, M.C.A., Euclides, V.B.P., Mancio, A.B., Medeiros, S.R., Costa, J.A.R. and Oliveira, R.L. (2013) Intake and Performance of Yearling Steers Grazing Guineagrass (Panicum maximum cv. Tanzânia) Pasture Supplemented with Different Energy Sources. Asian-Australasian Journal of Animal Sciences, 26, 349-357. http://dx.doi.org/10.5713/ajas.2012.12226

[16] Van Soest, P.J. (1994) Nutritional Ecology of the Ruminant. 2nd Edition, Cornell University Press, Ithaca.

[17] Gomes, R.A., Lempp, B., Jank, L., Carpejani, G.C. and Morais, M.G. (2011) Características Anatômicas e Morfofisiológicas de Lâminas Foliares de Genótipos de Panicum maximum. Pesquisa Agropecuária Brasileira, 46, 205-211. http://dx.doi.org/10.1590/S0100-204X2011000200013

[18] Nelson, C.J. and Moser, L.E. (1994) Plant Factors Affecting Forage Quality. In: Farey Jr., G.C., Ed., Forage Quality, Evaluation, and Utilization, America Society of Agronomy, Wisconsin, 59-114. 